\title{
The Modified Conceptual Understanding Layer "PKS" Model As An Alternative Assessment Tool On Hots Type Problems
}

\author{
Viktor Sagala $^{1}$, Ahmad Hatip ${ }^{2}$, Sucipto ${ }^{3}$, Kusmiyati ${ }^{4}$ \\ \{viktor.sagala@unitomo.ac.id ${ }^{1}$, ahmad.hatip@unitomo.ac.id ${ }^{2}$, sucipto@unitomo.ac.id ${ }^{3}$ \} \\ ${ }^{1,2,3,4}$ Universitas Dr. Soetomo Surabaya, Indonesia
}

\begin{abstract}
The purpose of this paper is to explain the results of the study of the possibility of applying the Modified Conceptual Understanding Layer Pirie-Kieren-Sagala (PKS) Model as an alternative assessment tool. This literature research uses research subjects in the form of several articles which have been published in various scientific journals. Five articles have been selected, compiled, compiled, reduced, classified and concluded according to the assessment model proposed. The articles focus on learning the PRAKTAK model, the results of the HOTS type problem solving and the conceptual understanding layer. The results of the analysis show that the subjects in the six research results reached a score of $0,1,2,3,4,5,6$ and 7. Therefore, the Modified Conceptual Understanding Layer "PKS" Model can be applied as an alternative assessment of the mathematics learning outcomes of HOTS type problems. The indicators of each layer of understanding can be used to differentiate the fulfillment of the learner's understanding layer, with seven scoring scales.
\end{abstract}

Keywords: Understanding layer, modified PKS understanding layers model, alternative assessment, PRAKTAK learning model, HOTS mathematical learning outcomes.

\section{Introduction}

Research on the understanding layer is still only developing in the past three years in Indonesia. The understanding layer hypothesized by Pirie-Kieren [1] consists of primitive knowing, image-making, an image having, property noticing, formalizing, observing, structuring, and inventing [2]. Then the model was developed by cognitive psychology experts and researchers, including Meel [3], Manu [4], Droujkova [5], Martin [6], Parameswaran [7], Sagala [2], and Sagala [8]. They add and refine the indicators, so the latter is called the PirieKieren-Sagala (PKS) Modification Understanding Layer Model, while the hypothesized model was originally called the Pirie-Kieren (PK) Original Understanding Layer Model. The Pirie-Kieren-Sagala (PKS) Modification understanding layer model will be used as an alternative assessment tool.

Modified „PKS“ Model, originally intended by Pirie-Kieren to describe the growth of concepts that students have [1]. After the model was refined by researchers since 2003 up to Meel [3] to Sagala 2017 [8], in this final phase, Sagala \& Hatip [9] and Sagala, Kusmiyati \& Sucipto [10] designed and applied to learn practicum-axiomatic (PRAKTAK) models to improve the achievement of the student's understanding layer. 


\section{Understanding Layer}

Understanding one's mathematical concepts is the ability to carry out abstracting, constructing and representing concepts [8]. As explained in the introduction, that the Modified "PKS" Model has 21 (twenty-one) indicators for 8 layers, as in the following table.

Table 1. The indicators of each understanding layer are modified Pirie-Kieren-Sagala models [2]

\begin{tabular}{|c|c|c|}
\hline Layer & Indikator of understanding & Coding \\
\hline \multirow{3}{*}{$\begin{array}{l}\text { Primitive } \\
\text { knowing }\end{array}$} & Make an initial effort in understanding the new definition & Pk1 \\
\hline & Bringing prior knowledge to the next layer of understanding, & $\mathrm{Pk} 2$ \\
\hline & Through actions that involve definitions or represent definitions & $\mathrm{Pk} 3$ \\
\hline \multirow{3}{*}{$\begin{array}{l}\text { Image- } \\
\text { making }\end{array}$} & Make a picture based on previous knowledge & $\operatorname{Im} 1$ \\
\hline & Develop certain ideas & $\operatorname{Im} 2$ \\
\hline & Make a picture of a concept through pictures or examples & $\operatorname{Im} 3$ \\
\hline \multirow[t]{2}{*}{ Image having } & Have a description of a topic & Ih1 \\
\hline & Make a mental picture of a topic without having to work on examples & Ih2 \\
\hline \multirow[t]{2}{*}{$\begin{array}{l}\text { Property } \\
\text { noticing }\end{array}$} & $\begin{array}{l}\text { Mampu mengkombinasikan aspek-aspek dari sebuah topik untuk } \\
\text { membentuk sifat yangrelevan dan spesifik }\end{array}$ & Pn1 \\
\hline & Able to combine aspects of a topic to form relevant and specific traits & Pn2 \\
\hline \multirow[t]{2}{*}{ Formalizing } & $\begin{array}{l}\text { Making abstractions of a mathematical concept based on the } \\
\text { characteristics that arise }\end{array}$ & Fo1 \\
\hline & $\begin{array}{l}\text { Able to understand a formal definition or algorithm of the Mathematics } \\
\text { concept }\end{array}$ & Fo2 \\
\hline \multirow[t]{4}{*}{ Observing } & $\begin{array}{l}\text { Able to coordinate formal activities at the previous level so that they can } \\
\text { use them on related problems }\end{array}$ & Ob1 \\
\hline & $\begin{array}{l}\text { Able to associate understanding of mathematical concepts with new } \\
\text { knowledge structures }\end{array}$ & $\mathrm{Ob} 2$ \\
\hline & Able to make formal statements about a mathematical concept & Ob3 \\
\hline & Able to look for a pattern to determine an algorithm or theorem & Ob4 \\
\hline \multirow[t]{2}{*}{ Structuring } & $\begin{array}{l}\text { Able to associate the relationship between a theorem and other theorems } \\
\text { and be able to prove it based on logical arguments }\end{array}$ & St1 \\
\hline & $\begin{array}{l}\text { Being able to prove the relationship between a theorem and the other } \\
\text { theorems is axiomatic }\end{array}$ & St2 \\
\hline \multirow[t]{3}{*}{ Inventing } & Having a complete structured understanding & In1 \\
\hline & Being able to create new questions that can grow into a new concept & In2 \\
\hline & Being able to create new questions that can grow into a new concept & In3 \\
\hline
\end{tabular}

An overview of the original model's understanding layer and the results of modifications are presented below. 


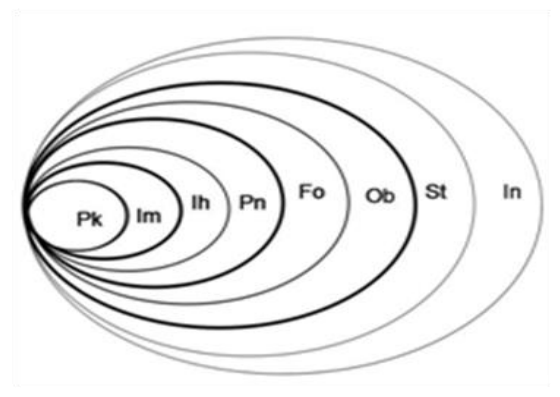

Fig. 1. The Original Pirie-Kieren (PK) Original Conceptual Understanding Layer Model [2]

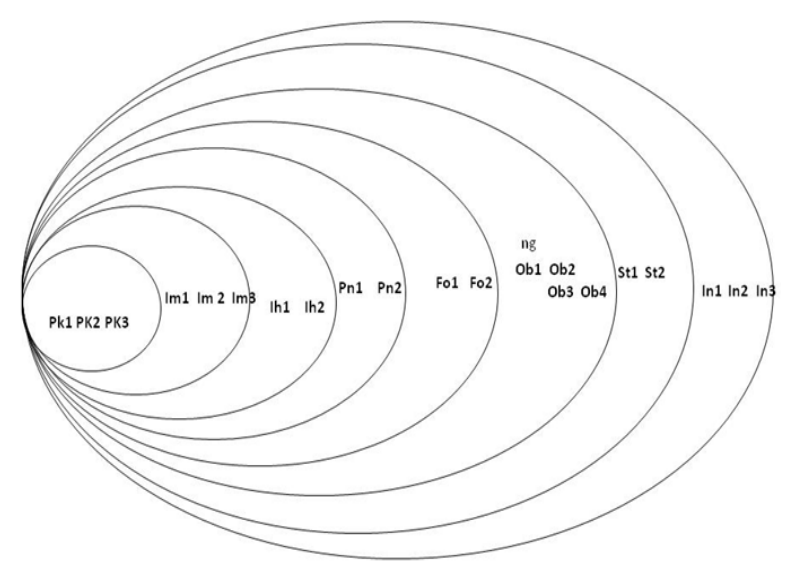

Fig. 2. The Modified Pirie-Kieren-Sagala (PKS) Conceptual Understanding Layer Model [8]

The PRAKTAK learning model that was developed by Sagala [10] was applied in Geometry learning in the Mathematics Education Study Program, Faculty of Teacher Training and Education, Dr. Soetomo University Surabaya (Program Studi Pendidikan Matematika, Fakultas Keguruan dan Ilmu Pendidikan, Universitas Dr. Soetomo), . PRAKTAK is a learning model that combines practicum and axiomatic methods. As is known that practicum methods are usually applied to science learning [11], while axiomatic methods are usually applied in mathematics learning. The syntax of PRAKTAK learning is presented as follows :

Table 2. The Syntax of PRAKTAK Learning Model [10]

\begin{tabular}{ccll}
\hline Step & \multicolumn{1}{c}{ Lectuure's Action } & \multicolumn{2}{c}{ Student's Action } \\
\hline Preliminary & 1) $\begin{array}{l}\text { Presenting problems and learning } \\
\text { objectives }\end{array}$ & $\begin{array}{l}\text { Pay attention to the problems and } \\
\text { objectives presented } \\
\text { Soting the delivery of practical } \\
\text { instructions }\end{array}$
\end{tabular}

Core

Closing
3) Facilitating, observing and giving guidance in the implementation of practical findings and proof of formulas/theorems

4) Facilitating, observing and giving guidance on the presentation of practical work results

5) Carry out axiomatic proof/formula theorem (explain facts, concepts, principles, procedures)

6) Together with students to carry out evaluations, reflections/conclusions, and delivery of follow-up carry out practical findings and proof of formulas/theorems

Carry out the presentation of practical work results

Carry out axiomatic proof/formula theorem (explain facts, concepts, principles, mathematical procedures)

Together with the lecturers, they conducted evaluations, reflections/conclusions and delivered follow-up 
The characteristics of HOTS type revealed Miri [12] include non-algorithmic, complex, many solutions, involving a variety of decision-making and interpretation, applying many criteria, and requiring a lot of effort. Conklin [13] states the characteristics of HOTS as follows: "characteristics of higher-order thinking skills: higher-order thinking skills encompass both critical thinking and creative thinking" meaning that the characteristics of high-level thinking skills include critical thinking and creative thinking. Critical and creative thinking are two very basic human abilities because both of them can encourage someone to always look at each problem faced critically and try to find answers creatively so that a new thing that is better and beneficial to their life is obtained [14]; Miri [12]. Conclik [13] divides the level of ability to solve HOTS questions into 4 levels, namely level 1 to level 4 . Level 1 is described as the level of withdrawal where facts, information, or procedures are recalled. This requires the lowest level of thinking. Level 2 is described as a level of skill or concept. Usually, students classify, organize, estimate, collect, display, observe, and compare data. They use the information they know. This level requires deeper thinking from level 1. Level 3 is characterized by strategic thinking. Reasoning, planning, and making guesses. Open tasks do not always make this level of activity high-level thinking. Students must give reasons to choose their answers. Students describe conclusions, support them with evidence, or determine which concepts will be applied to solve the problem. Level 4 is described as expanded thinking and is the highest level of thought. This is characterized by complex reasoning that students use to make interdisciplinary connections. Often activities at this level take a long time, must only because a project requires a specified time period. This level requires investigation of a kind of project that shows the results of complicated thinking.

If we look at the indicators of the problem of High Order Think Skill (HOTS), there is a conformity with the understanding layer of the Pirie-Kieren-Sagala (PKS) Modification model. There is a red thread between indicators of HOTS questions with indicators of the Pirie-Kieren-Sagala (PKS) understanding layer in table 1.

\section{Research Method}

The approach of this research is qualitative descriptive. The data collected from several published studies in the form of articles is linked to one another, then reduced, classified, concluded [15] its suitability for the possibility of using the model proposed as an alternative assessment. Given that this seven-scale assessment has been applied to the assessment of lecturers' performance and perceptions [16], the rating scale is proposed as follows:

Table 3. Categorization of Compliance with the Pirie-Kieren-Sagala Model Understanding Layer Indicator

\begin{tabular}{llcl}
\hline \multicolumn{1}{c}{ Understanding Layer } & \multicolumn{1}{c}{ Comprehension indicators are met } & Score & \multicolumn{1}{c}{ Category } \\
\hline Primitive Knowing & $\mathrm{Pk} 1, \mathrm{Pk} 2, \mathrm{Pk} 3$ & 0 & Does not meet \\
Image-making & $\mathrm{Pk} 1, \mathrm{Pk} 2, \mathrm{Pk} 3, \mathrm{Im} 1, \mathrm{Im} 2, \mathrm{Im} 3$ & 1 & Very poorly fulfilled \\
Image having & $\mathrm{Pk} 1, \mathrm{Pk} 2, \mathrm{Pk} 3, \mathrm{Im} 1, \mathrm{Im} 2, \mathrm{Im} 3, \mathrm{Ih} 1, \mathrm{Ih} 2$ & 2 & Less fulfilling \\
Property noticing & $\mathrm{Pk} 1, \mathrm{Pk} 2, \mathrm{Pk} 3, \mathrm{Im} 1, \mathrm{Im} 2, \mathrm{Im} 3, \mathrm{Ih} 1, \mathrm{Ih} 2$, & 3 & Rather fulfilling \\
& $\mathrm{Pn} 1, \mathrm{Pn} 2$ & & \\
Formalizing & $\mathrm{Pk} 1, \mathrm{Pk} 2, \mathrm{Pk} 3, \mathrm{Im} 1, \mathrm{Im} 2, \mathrm{Im} 3, \mathrm{Ih} 1, \mathrm{Ih} 2$, & 4 & Enough to fulfill \\
& $\mathrm{Pn} 1, \mathrm{Pn} 2, \mathrm{Fo} 1, \mathrm{Fo} 2$ & & \\
\hline
\end{tabular}




\begin{tabular}{llcl}
\hline Observing & Pk1, Pk2, Pk3, Im1,Im2, Im3, Ih1,Ih2, & 5 & Fulfill well \\
& Pn1,Pn2, Fo1,Fo2, Ob1,Ob2,Ob3,Ob4 & & \\
Structuring & Pk1, Pk2, Pk3, Im1,Im2, Im3, Ih1,Ih2, & 6 & Fulfill it very well \\
& Pn1,Pn2, Fo1, Fo2, Ob1,Ob2,Ob3,Ob4, & & \\
& St1,St2 & & \\
Inventising & Pk1, Pk2, Pk3, Im1,Im2, Im3, Ih1,Ih2, & 7 & Fulfill it perfectly \\
& Pn1,Pn2, Fo1,Fo2, Ob1,Ob2,Ob3,Ob4, & \\
& St1,St2, In1,In2,In3
\end{tabular}

\section{Results and Discussion}

Some data sources used include articles (1) Profil Lapisan Pemahaman Konsep Turunan Fungsi dan Bentuk Folding Back Mahasiswa Calon Guru Berkemampuan Matematika Tinggi Berdasarkan Gender Jurnal MUST Vol 1, No 2 (2016) UM Surabaya[2], (2) Struktur Lapisan Pemahaman Konsep Turunan Fungsi Mahasiswa Calon Guru Matematika Jurnal Didaktik Matematika ISSN 23554185 (print) 2548 8546(online) http://jurnal.unsyiah.ac.id/DM [8], (3) Profil Lapisan Pemahaman Konsep Siswa SMP Terkait Garis Tinggi Segitiga, Jurnal Ilmiah : SOULMATH, Vol 6(2), Oktober 2018 [17], (4) Peningkatan Lapisan Pemahaman Konsep Bangun Datar Mahasiswa Calon Guru Dengan Penerapan Model Pembelajaran PRAKTAK MUST: Journal of Mathematics Education, Science and Technology Vol. 3, No. 2, Desember 2018 [10], (5) Peningkatan Lapisan Pemahaman Konsep Luas Bangun Datar Mahasiswa melalui Model Pembelajaran PRAKTAK, Jurnal Didaktik Matematika Vol.5,No.2,September 2018 ISSN2355-4185(p), 2548-8546(e) UNSYAH Banda Aceh [9], (6) Layers of Conceptual Understanding of Fractions among Elementary Student i-Manager's Journal on Educational Psychology; Nagercoil (Nov 2018-Jan 2019) [18].

Article 1 shows that high capable male and female subjects meet the primitive knowing until the structuring indicator plus one of inventising indicator, namely In1. Both subjects meet the inventising layer (namely inventisingoid) [2]. Article 2 shows that the two subjects meet the primitive knowing layer indicator until structuring to inventory. Both subjects meet the Structuring layer [8]. Article 3 shows that the conceptual understanding of junior high school students is related to the high line of triangles as follows: 1) on concepts related to the understanding of the line of high triangles of highly capable subjects (S1) in the Inventising layer, moderate ability (S2) in the Structuring layer and low capable subjects (S3) in the Formalizing layer; 2) in the related concept of drawing a high line of pointed triangle of highability subject (S1) in the Inventising layer, medium-capable subject (S2) in the Structuring layer and low-ability subject (S3) in the Image Having layer; and 3) on the concepts related to drawing a high line of blunt triangles of high-ability subjects (S1) in the Structuring layer, moderate-capable subjects (S2) in the Property Noticing layer and low-ability subjects (S3) in the Image Having layer [17]. Article 4 shows that the subject meets the primitive knowing layer until property noticing, before applying PRATAK learning. Article 4 shows that the subject meets the primitive knowing layer until property noticing, before applying PRATAK learning. Furthermore, after the application of PRATAK learning, the subject fulfilled all the primitive knowing to formalizing layer indicators, as well as two of the four 6th layer indicators (observing), namely $\mathrm{Ob} 1$ and $\mathrm{Ob} 2$. Thus the subject meets the semi-observing layer. Article 5 shows that the subject meets the primitive knowing layer until property noticing, before applying PRATAK learning. Furthermore, after the application of PRATAK learning, the subject fulfilled all the indicators of the primitive knowing layer until observing, thus the subject filled the observing layer. Article 6 shows that, based on the work done by the 
students, the results show that in terms of layers of conceptual understanding, from the beginning of the interview to the end of the interview; Subject 1 demonstrated understanding layers from Primitive Knowing (Pk) through Property Noticing (Pn), Subject 2 demonstrated understanding layers from Image Making (Im) through Property Noticing (Pn); and Subject 3 demonstrated understanding layers from Image Making (Im) through Formalizing [18]. Scoring recapitulation obtained from the six articles can be presented below:

Table 4 Recapitulation of Compliance with the Pirie-Kieren-Sagala Model Understanding Layer Indicator according to Six Articles

\begin{tabular}{|c|c|c|c|c|}
\hline Article & $\begin{array}{l}\text { Understanding indicators are } \\
\text { met }\end{array}$ & Condition & $\begin{array}{l}\text { Layer Fulfillment } \\
\text { Category }\end{array}$ & Score \\
\hline 1 & $\begin{array}{l}\text { Pk1, Pk2, Pk3, Im1,Im2, Im3, } \\
\text { Ih1,Ih2, Pn1,Pn2, } \\
\text { Fo1,Fo2,Ob1,Ob2,Ob3, Ob4, } \\
\text { St1,St2, In1 }\end{array}$ & & Inventisingoid & 7 \\
\hline 2 & $\begin{array}{l}\text { Pk1, Pk2, Pk3, Im1,Im2, Im3, } \\
\text { Ih1,Ih2, Pn1,Pn2, } \\
\text { Fo1,Fo2,Ob1,Ob2,Ob3, Ob4, } \\
\text { St1,St2 }\end{array}$ & & Structuring & 6 \\
\hline \multirow[t]{8}{*}{3} & $\begin{array}{l}\text { Pk1, Pk2, Pk3, Im1,Im2, Im3, } \\
\text { Ih1,Ih2, Pn1,Pn2, Fo1,Fo2, } \\
\text { Ob1,Ob2,Ob3,Ob4, St1,St2, } \\
\text { In1,In2,In3 }\end{array}$ & $\begin{array}{l}\text { Definition of triangle height } \\
\text { ST }\end{array}$ & Inventising & 7 \\
\hline & $\begin{array}{l}\text { Pk1, Pk2, Pk3, Im1,Im2, Im3, } \\
\text { Ih1,Ih2, Pn1,Pn2, Fo1,Fo2, } \\
\text { Ob1,Ob2,Ob3,Ob4, St1,St2 }\end{array}$ & $\begin{array}{l}\text { Definition of triangle height } \\
\text { SS }\end{array}$ & Structuring & 6 \\
\hline & $\begin{array}{l}\text { Pk1, Pk2, Pk3, Im1,Im2, Im3, } \\
\text { Ih1,Ih2, Pn1,Pn2, Fo1,Fo2 }\end{array}$ & $\begin{array}{l}\text { Definition of triangle height } \\
\text { SR }\end{array}$ & Formalizing & 4 \\
\hline & $\begin{array}{l}\text { Pk1, Pk2, Pk3, Im1,Im2, Im3, } \\
\text { Ih1,Ih2, Pn1,Pn2, Fo1,Fo2, } \\
\text { Ob1,Ob2,Ob3, Ob4, St1,St2, } \\
\text { In1,In2,In3 }\end{array}$ & $\begin{array}{l}\text { Definition of the height of a } \\
\text { pointed triangle ST }\end{array}$ & Inventising & 7 \\
\hline & $\begin{array}{l}\text { Pk1, Pk2, Pk3, Im1,Im2, Im3, } \\
\text { Ih1,Ih2, Pn1,Pn2, Fo1,Fo2, } \\
\text { Ob1,Ob2,Ob3, Ob4, St1,St2 }\end{array}$ & $\begin{array}{l}\text { Definition of the height of } \\
\text { a pointed triangle SS }\end{array}$ & Structuring & 6 \\
\hline & $\begin{array}{l}\text { Pk1, Pk2, Pk3, Im1,Im2, Im3, } \\
\text { Ih1,Ih2, Pn1,Pn2, }\end{array}$ & $\begin{array}{l}\text { Definition of the height of a } \\
\text { pointed triangle SR }\end{array}$ & Property noticing & 3 \\
\hline & $\begin{array}{l}\text { Pk1, Pk2, Pk3, Im1,Im2, Im3, } \\
\text { Ih1,Ih2, Pn1,Pn2, }\end{array}$ & $\begin{array}{l}\text { Definition of the height of a } \\
\text { pointed triangle SR }\end{array}$ & Image having & 2 \\
\hline & $\begin{array}{l}\text { Pk1, Pk2, Pk3, Im1,Im2, Im3, } \\
\text { Ih1,Ih2, Pn1,Pn2, Fo1,Fo2, } \\
\text { Ob1,Ob2,Ob3, Ob4, St1,St2 }\end{array}$ & $\begin{array}{l}\text { Definition of the height of } \\
\text { blunt triangle ST }\end{array}$ & Property noticing & 3 \\
\hline 4 & Pk1, Pk2, Pk3, Im1,Im2, Im3, & before the implementation & Observing & 4 \\
\hline
\end{tabular}




\begin{tabular}{|c|c|c|c|c|}
\hline & Ih1,Ih2, Pn1,Pn2, Fo1,Fo2 & $\begin{array}{l}\text { of PRAKTAK learning } \\
\text { model }\end{array}$ & & \\
\hline & $\begin{array}{l}\text { Pk1, Pk2, Pk3, Im1,Im2, Im3, } \\
\text { Ih1,Ih2, Pn1,Pn2, Fo1,Fo2, } \\
\text { Ob1,Ob2,Ob3, Ob4 }\end{array}$ & $\begin{array}{l}\text { after implementation of } \\
\text { PRAKTAK learning model }\end{array}$ & Formalizing & 5 \\
\hline \multirow[t]{2}{*}{5} & $\begin{array}{l}\text { Pk1, Pk2, Pk3, Im1,Im2, Im3, } \\
\text { Ih1,Ih2, Pn1,Pn2, Fo1,Fo2 }\end{array}$ & $\begin{array}{l}\text { before implementation of } \\
\text { PRAKTAK learning model }\end{array}$ & Semi observing & 4 \\
\hline & $\begin{array}{l}\text { Pk1, Pk2, Pk3, Im1,Im2, Im3, } \\
\text { Ih1,Ih2, Pn1,Pn2, Fo1,Fo2, } \\
\text { Ob1,Ob2 }\end{array}$ & $\begin{array}{l}\text { after implementation of } \\
\text { PRAKTAK learning model }\end{array}$ & Formalizing & 5 \\
\hline \multirow[t]{6}{*}{6} & $\mathrm{Pk}$ & Subject 1 (beginning) & Primitive Knowing & 0 \\
\hline & Pk, Im, Ih, Pn & Subject 1 (ending) & Property noticing & 3 \\
\hline & $\mathrm{Pk}, \mathrm{Im}$ & Subject 2 (beginning) & Image making & 1 \\
\hline & $\mathrm{Pk}, \mathrm{Im}, \mathrm{Ih}, \mathrm{Pn}$ & Subject 2 (ending) & Property noticing & 3 \\
\hline & $\mathrm{Pk}, \mathrm{Im}$ & Subject 3 (beginning) & Image making & 1 \\
\hline & Pk, Im, Ih, Pn, Fo & Subject 3 (ending) & Formalizing & 4 \\
\hline
\end{tabular}

The table above shows that the subjects in various articles meet the layers of understanding of the PKS model with varying scores, namely $0,1,2,3,4,5,6,7$. The table above shows that the subjects in various articles meet the layers of understanding of the „PKS“ model with varying scores, namely $0,1,2,3,4,5,6,7$. This shows that the modified „PKS“ understanding layer model is suitable to be applied as an alternative assessment tool for learning outcomes of HOTS type questions.

\section{Conclusion}

The results of the analysis show that the subjects in the six research results reached a score of $0,1,2,3,4,5,6$ and 7. Therefore, the Modified Conceptual Understanding Layer "PKS" Model can be applied as an alternative assessment of the mathematics learning outcomes of HOTS type problems. The indicators of each layer of understanding can be used to differentiate the fulfillment of the learner's understanding layer, with seven scoring scales.

\section{References}

[1] S. Pirie and T. Kieren, "Growth in Mathematical Understanding: How we can characterize it an How can Represent Education Studies in Mathematics," vol. 9, pp. 160-164, 1994.

[2] V. Sagala, "Profil Lapisan Pemahaman Konsep Turunan Fungsi dan Bentuk Folding Back Mahasiswa Calon Guru Berkemampuan Matematika Tinggi Berdasarkan Gender," MUST J. Math. Educ. Sci. Technol., vol. 1, no. 2, pp. 183-198, 2016.

[3] D. . Meel, "Model and Theories of Mathematical Understanding: Comaring PirieKieren`s Model of the Growth of Mathematical Understanding and APOS Theory," $C$. Issues Math. Educ., vol. 12, 2002.

[4] Manu, "Language Switching and Mathematical Understanding in Tongan Clasrooms: An Investigation,” J. Educ. Stud., vol. 27, no. 2, 2005.

[5] A. Droujkova, B. Berenson, K. Slaten, and S. Tombes, "A Conceptual Framework for Studying Teacher Preparation: The Pirie-Kieren Model, Collective Understanding an Metafor," in Proceeding of 29th Conference of the International Group for the Mathematical Education, 2011, vol. 2, pp. 289-296. 
[6] L. C. Martin, "Folding back and the dynamical growth of mathematical understanding: Elaborating the Pirie-Kieren Theory The Journal of Mathematical Behavior," vol. 27, no. 1 , pp. $64-85,2008$.

[7] R. ] Parameswaran, "Expert Mathematicians Approach to Understanding Definition," Math. Educ., vol. 20, no. 1, pp. 45-51, 2010.

[8] V. Sagala, "Struktur Lapisan Pemahaman Konsep Turunan Fungsi Mahasiswa Calon Guru Matematika," J. Didakt. Mat., vol. 4, no. 2, 2017.

[9] V. Sagala and A. Hatip, "Peningkatan Lapisan Pemahaman Konsep Luas Bangun Datar Mahasiswa melalui Model Pembelajaran PRAKTAK," J. Didakt. Mat., vol. 5, no. 2, 2018.

[10] V. Sagala, Kusmiyati, and Sucipto, "Peningkatan Lapisan Pemahaman Konsep Bangun Datar Mahasiswa Calon Guru Dengan Penerapan Model Pembelajaran PRAKTAK," MUST J. Math. Educ. Sci. Technol., vol. 3, no. 2, pp. 152-164, 2018.

[11] M. Nur, "Ketrampilan-ketrampilan Proses Sains," Pus. Sains dan Mat. Sekol. UNESA, 2011.

[12] B. Miri, B. David, and Z. Uri, "Purposely teaching for the promotion of higher-order thinking skills: A case of critical thinking," Res. Sci. Educ., vol. 37, no. 4, pp. 353$369,2007$.

[13] W. Conclin, Strategies for Developing Higher-Order Thinking Skills, 2012.

[14] A. Budiman and Jailani, "Pengembagan Instrumen Asesmen Higher Order Thinking Skil (HOTS) Pada Mata Pelajaran Matematika SMP Kelas VIII Semester 1, Jurnal Riset Pendidikan Matematika UNY," vol. 1, no. 2, pp. 139-151, 2014.

[15] M. J, "Metodologi Penelitian Kuantitatif Edisi Revisi Bandung PT Remaja Rosdakarya," 2010.

[16] Ristekdikti, "PEDOMAN PEMBERIAN SKOR DESKRIPSI DIRI DOSEN," 2017. [Online]. Available: https://diahsastri.files.wordpress.com/2017/12/pedomanpemberian-skor-deskripsi-diri-dosen.pdf.

[17] R. . Safitri, S. Mulyani, and N. Ratu, "Profil Lapisan Pemahaman Konsep Siswa SMP Terkait Garis Tinggi Segitiga,” J. Ilm. SOULMATH, vol. 6, no. 2, pp. 65-78, 2018.

[18] S. Rahayuningsih, C. Sa'dijah, Sukoriyanto, and Abadyo, "Layers of Conceptual Understanding of Fractions among Elementary Student," i-Manager's J. Educ. Psychol. Nagercoil, vol. 12, no. 3, 2019. 